\title{
15 Fruiting Body Formation in Basidiomycetes
}

\author{
Jordi F. Pelkmans ${ }^{1}$, Luis G. Lugones ${ }^{1}$, Han A.B. Wösten ${ }^{1}$
}

\section{CONTENTS}

I. Introduction 387

II. Development of Emergent Structures ...... 387

III. Regulation of Fruiting Body Formation .... 389 A. Environmental Signals ................ 389

B. Mating-Type Genes as Master Regulators . 391

C. Other Regulatory Genes ................. 393

D. Nuclear Positioning .................. 395

IV. Structural Proteins and Enzymes Involved in

Fruiting ............................. 396

A. Hydrophobins $\ldots \ldots \ldots \ldots \ldots \ldots \ldots \ldots \ldots \ldots, \ldots \ldots$

B. Lectins ........................... 397

C. Haemolysins ....................... 397

D. Oxidative Enzymes .................. 398

E. Expansins ............................. 398

V. Conclusions ........................ 398

References ........................... 399

\section{Introduction}

Fruiting bodies have evolved in the fungal kingdom to produce and disperse sexual spores. These reproductive structures of the Homobasidiomycota generally contain specialised cells, basidia, in which the genetically different parental haploid nuclei fuse. The resulting diploid cells immediately undergo meiosis to form haploid basidiospores. In some cases, diploid nuclei are already formed in the vegetative mycelium, as in Armillaria species (Ullrich and Anderson 1978; Grillo et al. 2000). After discharge, germination of the haploid basidiospores results in homokaryotic mycelia. These mycelia can fuse and, depending on an often complex system of mating-type genes

\footnotetext{
${ }^{1}$ Microbiology, Utrecht University, Padualaan 8, $3584 \mathrm{CH}$ Utrecht, The Netherlands; e-mail: h.a.b.wosten@bio.uu.nl
}

(see Freihorst et al. 2016), produce a heterokaryotic mycelium that is fertile. Consequently, it forms fruiting bodies under appropriate environmental conditions. Basidiomycetes behaving according to this scheme are in the majority and are called heterothallic (i.e. selfincompatible). From a teleological point of view, this makes sense because it ensures that the diploid basidia produce recombinant meiotic progeny. A minority of basidiomycetes (about $10 \%$; Whitehouse 1949) are homothallic (i.e. self-compatible). Recently, it was shown that unisexual reproduction also creates diversity (Ni et al. 2013), which would explain the existence of homothallic species from an evolutionary point of view.

This review discusses the regulation of fruiting body formation in homobasidiomycetes and the role structural proteins and enzymes play in this process. Related topics such as morphogenesis, cytology and mathematical modelling are discussed in Wells and Wells (1982), Moore et al. (1985), Wessels (1993), Chiu and Moore (1996), Moore (1998), Kües (2000), Meskauskas et al. (2004). Fruiting of commercially important species is reviewed in van Griensven (1988), Kües and Liu (2000), Kothe (2001) and Sánchez (2010).

\section{Development of Emergent Structures}

\section{Formation of a Feeding Mycelium}

Fruiting bodies develop from a vegetative mycelium. Formation of this mycelium starts with the germination of an asexual or sexual 
spore. Hyphae growing out of these spores grow at their tips, while branching subapically (Wessels 1986, 1990). Hyphal fusion promotes the formation of an elaborate hyphal network (Chap. 6 in The Mycota, Volume VIII).

The vegetative mycelium degrades and colonises organic substrates by means of extracellular enzymes that are secreted at tips of growing hyphae (Wösten et al. 1991; Moukha et al. 1993). The degradation products are taken up and serve as nutrients. They can also be transported to other parts of the mycelium, which would explain why some fungi can grow for considerable distances over nonnutritive surfaces (Jennings 1984, see Chap. 9 in Volume I of The Mycota, 1994). Mass transport of water and nutrients through the mycelium implies that the cytoplasm is continuous within the mycelium. This would be mediated by the large pores (diameters up to $500 \mathrm{~nm}$ ) within the septa that compartmentalise hyphae. These pores, however, are not always open, at least in Schizophyllum commune (van Peer et al. 2009). As many as $90 \%$ of the subapical septa can be closed when $S$. commune is growing on glucosecontaining medium. Septal closure is strongly reduced when $S$. commune is grown in the absence of this carbon source, while high temperature, hypertonic conditions or exposure to the antibiotic nourseothricin increase plugging incidence. So far, the plugging state of septa has not been assessed when S. commune (or other basidiomycetes) grows under natural conditions and how this affects long- and short-distance transport of nutrients. Closure of the septal pores is mediated by the septal pore cap (SPC) (van Driel et al. 2008; van Peer et al. 2010). Inactivation of $s p c 33$ that encodes a structural SPC protein results in reduced vegetative growth and retarded fruiting body formation (van Peer et al. 2010). It was proposed that this is caused by decreased turgor pressure due to the inability to close the septal pores. Septal closure may also allow for differentiation of hyphae within the vegetative mycelium, as was shown in Aspergillus niger (Wösten et al. 2013).

Translocation of water and nutrients is essential for fruiting body development. Fruiting body primordia of $S$. commune (Wessels 1965) and Coprinus cinereus (Coprinopsis cinerea) (Moore 1998) can arise at the expense of polymeric constituents of the supporting mycelium, while expanding fruiting bodies grow at the expense of both supporting mycelium and abortive fruiting body primordia. At the moment, it is not clear how much of this is due to movement of cytoplasm or to degradation and resynthesis of cellular components. Woolston et al. (2011) showed in A. bisporus that the heterologous protein $\beta$-glucuronidase is transported from the vegetative mycelium into the fruiting body. No evidence was obtained for translocation of its mRNA.

\section{Formation of Fruiting Bodies from the Vegeta- tive Mycelium}

Formation of fruiting bodies is a highly complex developmental process. A generalised scheme for formation of agaric fruiting bodies such as those of $C$. cinereus (Moore 1998; Kües 2000) is as follows: After a "critical mass" of vegetative mycelium has been formed, hyphae escape the substrate to grow into the air. These aerial hyphae form aggregates, which are called hyphal knots or nodules. Within the knots, hyphae aggregate forming a fruiting body initial. These initials are the first fruiting bodyspecific structures (Sánchez and Moore 1999; Sánchez et al. 2004; Kües et al. 2004). Initials can further develop into primordia. Primordia are characterised by the presence of all tissues that occur in a mature fruiting body. Only a fraction of the initials or primordia eventually will grow out into mature fruiting bodies. Possibly, stochastic processes and competition for translocated materials determine which initials further develop. Alternatively, and not mutually exclusive, developing fruiting bodies may repress outgrowth of neighbouring initials. Such a mechanism was proposed based on the observation that inactivation of $f$ st 3 of $S$. commune resulted in a high number of fruiting bodies. These $\Delta f s t 3$ fruiting bodies were smaller than those of the wild type (Ohm et al. 2010).

The lower part of primordia will develop into the stipe of a mature fruiting body, while the cap will be formed from the upper part. Within the cap, different tissues develop, which are not formed from meristems, as in plants, but result from the interaction of 

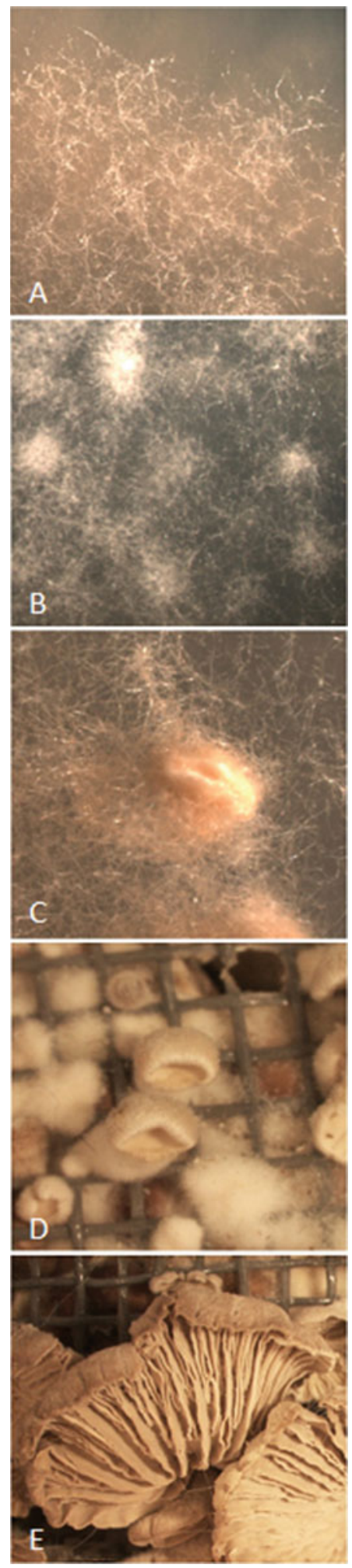

individual hyphae. The hymenium is one of the cap tissues, which consists of different cell types including the basidia. In the basidia, karyogamy and meiosis take place, ultimately resulting in basidiospores. The complexity of fruiting body development is also exemplified by the fact that formation of the different tissues overlaps in time. Moreover, cells in the developing mushroom differ in diameter, length, the number of septa, nuclei and vacuoles and molecular composition (e.g. the content of reserve carbohydrates; Moore 1998). The different cell types are the result of localised growth as well as apoptosis (Umar and van Griensven 1997; Wiemer et al. 2016).

Not all basidiomycetes follow the general morphogenetic pathway of fruiting body formation (Reijnders and Stafleu 1992; Watling 1996; Clémonçon 1997). For instance, the fruiting bodies of S. commune (Fig. 15.1) result from indeterminate growth of fruiting body primordia. Expansion of the cup-shaped primordia is not the result of intercalary growth but is due to continued apical growth and differentiation of hyphae in the primordium (Wessels 1993). Despite the variety in developmental programmes, their underlying regulation seems to be conserved, at least partly (see Sects. III.B and III.C).

\section{Regulation of Fruiting Body Formation}

\section{A. Environmental Signals}

Aerial growth is accompanied by drastic changes in exposure to oxygen, $\mathrm{CO}_{2}$ and light. These environmental factors can exert a profound influence on fruiting body development. Moreover, temperature, humidity, volatiles, $\mathrm{pH}$, salinity and availability of nutrients may play a decisive role (Madelin 1956; Manachère 1980; Kües and Liu 2000; Eastwood et al. 2013).

Fig. 15.1 Fruit body development of S. commune. Aerial hyphae (a) aggregate into stage I aggregates (b) from which stage II primordia develop (c). These primordia form cup-shaped structures (d) that further differentiate into mature fruiting bodies (e) 
The development of fruiting bodies is often, if not always, the result of a combination of environmental conditions. For instance, fruiting in Lentinula edodes is induced by light, moisture and low temperature (Ishikawa 1967; Matsumoto and Kitamoto 1987; Nakazawa et al. 2008). In the case of Agaricus bisporus, it was proposed that the volatile 1-octen-3-ol controls the early differentiation of vegetative hyphae to multicellular knots. A drop in temperature would subsequently control the differentiation of primordia in this basidiomycete, while the carbon dioxide level would determine the number of fruiting bodies that develop (Eastwood et al. 2013). Molecular mechanisms underlying regulation of fruiting by $\mathrm{CO}_{2}$ and light have been studied in some detail. This will be discussed in the following sections.

\section{Carbon Dioxide as a Signal for Fruiting Body Formation}

$\mathrm{CO}_{2}$ represses fruiting body development in a variety of basidiomycetes including A. bisporus and S. commune (Niederpruem 1963; Raudaskoski and Viitanen 1982; van Griensven 1988; Eastwood et al. 2013). Carbonic anhydrase most likely functions in $\mathrm{CO}_{2}$ sensing by converting this molecule in bicarbonate $\left(\mathrm{HCO}_{3}{ }^{-}\right)(\mathrm{Bahn}$ and Muhlschlegel 2006). This molecule stimulates adenylyl cyclase activity in Candida albicans and Cryptococcus neoformans (Klengel et al. 2005; Mogensen et al. 2006). Adenylyl cyclase may also be involved in $\mathrm{CO}_{2}$ sensing in fruiting body formation (Eastwood et al. 2013). In agreement, high levels of intracellular cAMP, the product of adenylyl cyclase, resulting from expression of dominant active $\mathrm{G}$ protein $\alpha$-subunits (SCGP-A and SCGP-C) reduce fruiting in S. commune (Yamagishi et al. 2002, 2004).

\section{Light as a Signal for Fruiting Body Formation}

Induction of primordia would be the only lightsensitive step in S. commune (Perkins 1969; Raudaskoski and Yli-Mattila 1985). Illumination for a few minutes was reported to be sufficient to induce primordia and, as a consequence, fruiting body development. However, recently, it was found that at least two develop- mental stages require light exposure at 2000 lux. Light is required for aggregate formation and for maturation of fruiting bodies (JF Pelkmans, unpublished data). Light is also required for several stages of fruiting body development in, for example, Coprinus congregatus (Manachère 1988) and C. cinereus (Tsusué 1969; Lu 1974; Kamada et al. 1978). Fruiting body formation in $C$. cinereus has at least five lightsensitive phases (Kües 2000; Lu 2000). Light is needed for the formation of initials, for maturation of primordia and for karyogamy. On the other hand, it negatively impacts hyphal knot formation and completion of meiosis. Thus, for fruiting bodies to develop, cycles of light and darkness are required. Light effects are local and are not spread systemically (Madelin 1956; Kertesz-Chaloupková et al. 1998).

Light is not required for the formation of mushrooms in A. bisporus. On the other hand, blue light initiates fruiting body formation in $C$. cinerea and S. commune (Perkins 1969; Durand 1985). The molecular mechanisms underlying blue light regulation in these basidiomycetes have been partly elucidated. Yet, blue light regulation is much better understood in Aspergillus nidulans and Neurospora crassa (Purschwitz et al. 2006; Bayram et al. 2010). We here briefly discuss what is known about light signalling in A. nidulans in relation to sexual development to illustrate how light signalling may operate in fruiting body formation in basidiomycetes. A. nidulans forms fruiting bodies preferentially in the dark. The phytochrome FphA is a red light receptor that represses sexual development (Blumenstein et al. 2005), while the blue light LreA/LreB receptor complex stimulates this process. The latter is concluded from inactivation of $\operatorname{lre} A$ or lreB (Purschwitz et al. 2008). Yet, lightregulated development is more complex as evidenced by the finding that fruiting body formation in a strain in which lre $A, \operatorname{lre} B$ and $f p h A$ are inactivated is less affected than in the $\Delta l r e A$ and the $\Delta$ lreB strains. LreA, LreB and PhyA form a light-sensing complex that also includes an activator of sexual development called VeA (Kim et al. 2002). VeA is also part of a complex 
with VelB, LaeA and VosA as core components (Bayram et al. 2010). Like the $\Delta v e A$ strain, the $\Delta v e l B$ strain does not form fruiting bodies (Bayram et al. 2008b). LaeA is a negative regulator of sexual development (Sarikaya Bayram et al. 2010) as evidenced by the finding that fruiting body development in the $\Delta l a e A$ strain is markedly increased in the light. Finally, $A$. nidulans has a second blue light sensor, CryA (Bayram et al. 2008a). CryA functions as a negative regulator of sexual development probably by integrating near-UV and blue light, resulting in repression of VeA-mediated initiation of sexual development.

C. cinerea has homologues for LreA, LreB, VeA, VelB, LaeA, a phytochrome and a cryptochrome-like photolyase. The role of these proteins is not yet known except for the LreA and LreB homologues, Dst1 and WC-2, respectively (Terashima et al. 2005; Nakazawa et al. 2011). Gene $d s t 2$ has also been proposed to be a photomorphogenic protein based on its phenotype (Kuratani et al. 2010). Genes dst1, $w c-2$ and $d s t 2$ were identified in a homokaryotic fruiting strain (i.e. with constitutively active A and $B$ mating-type pathways). This strain shows aberrant photomorphogenesis in that it forms dark stipes when grown continuously in the dark (Kamada et al. 2010). In other words, this strain does not need light for induction of initials but requires light for primordia maturation. Dark stipes in the wild type are obtained when cultures containing primordia are transferred to the dark. The pileus and stipe tissues at the upper part of the primordium remain rudimentary in the case of dark stipes, but the basal part of the primordium does elongate. Inactivation of $d s t 1, w c-2$ or $d s t 2$ in the homokaryotic fruiter impaired fruiting body development and resulted in the dark stipe phenotype when subjected to light.

The genome of $S$. commune contains orthologues of lreA, lreB, a putative cryptochrome, a phytochrome and genes encoding homologues of VeA, VelB and LaeA (Ohm et al. 2010). Moreover, $S$. commune contains a homologue of $d s t 2$. Genes $w c-1$ and $w c-2$ represent the lreA and $\operatorname{lre} B$ homologues of $S$. commune. Inactivation of these genes results in a blind phenotype. Dikaryons with both copies of $w c-1$ or $w c$ -
2 inactivated behave like monokaryons, unable to form mushrooms in white or blue light (Ohm et al. 2013; Fig. 15.2). The WC-1 and WC-2proteins contain two and one protein-binding Per-Arnt-Sim (PAS) domain, respectively. One of the PAS domains in WC-1 is a modified version, called a light-oxygen-voltage (LOV) domain. This domain is expected to bind flavin adenine dinucleotide (FAD), which is a chromophore that detects blue light. The WC-2protein has a predicted zinc finger domain of the GATA type. These data suggest that WC- 1 is the light receptor, while WC-2 would have a role as a transcriptional regulator. Compared to the wild type, 183 and 244 genes are more than twofold up- and downregulated in the $\Delta \mathrm{wc}-2 \Delta \mathrm{wc}-2$ dikaryon, respectively (Ohm et al. 2013). Hydrophobin genes are overrepresented in the downregulated genes (see Sect. IV. A). Moreover, expression of the transcription factor genes $c 2 h 2$ and hom 1 , known to be involved in fruiting body development (Ohm et al. 2011) (see Sect. III.C), is decreased in the $\Delta w c-2 \Delta w c-2$ dikaryon. Gene $c r y 1$ is also downregulated in the $\Delta w c-2 \Delta w c-2$ dikaryon. This suggests that the encoding cryptochrome/ photolyase plays a role in photobiology of $S$. commune (Ohm et al. 2013).

\section{B. Mating-Type Genes as Master Regulators}

Heterokaryons of heterothallic basidiomycetes are generally the life stage capable of fruiting. Fertile heterokaryons are the result of a mating between two homokaryons that have different mating-type genes (for further details, see Freihorst et al. 2016). Homokaryons of S. commune and $C$. cinereus contain one nucleus in each hyphal compartment and are therefore called monokaryons. On the other hand, the heterokaryons contain two nuclei (one of each mating partner) in each hyphal compartment and are, therefore, called dikaryons. The dikaryons of $S$. commune and $C$. cinereus are characterised by a clamp connection at each septum, which is formed during synchronous mitotic division of the two nuclei (Kües et al. 2016). Nuclear distribution and the presence of clamp connections are variable in heterobasidiomy- 


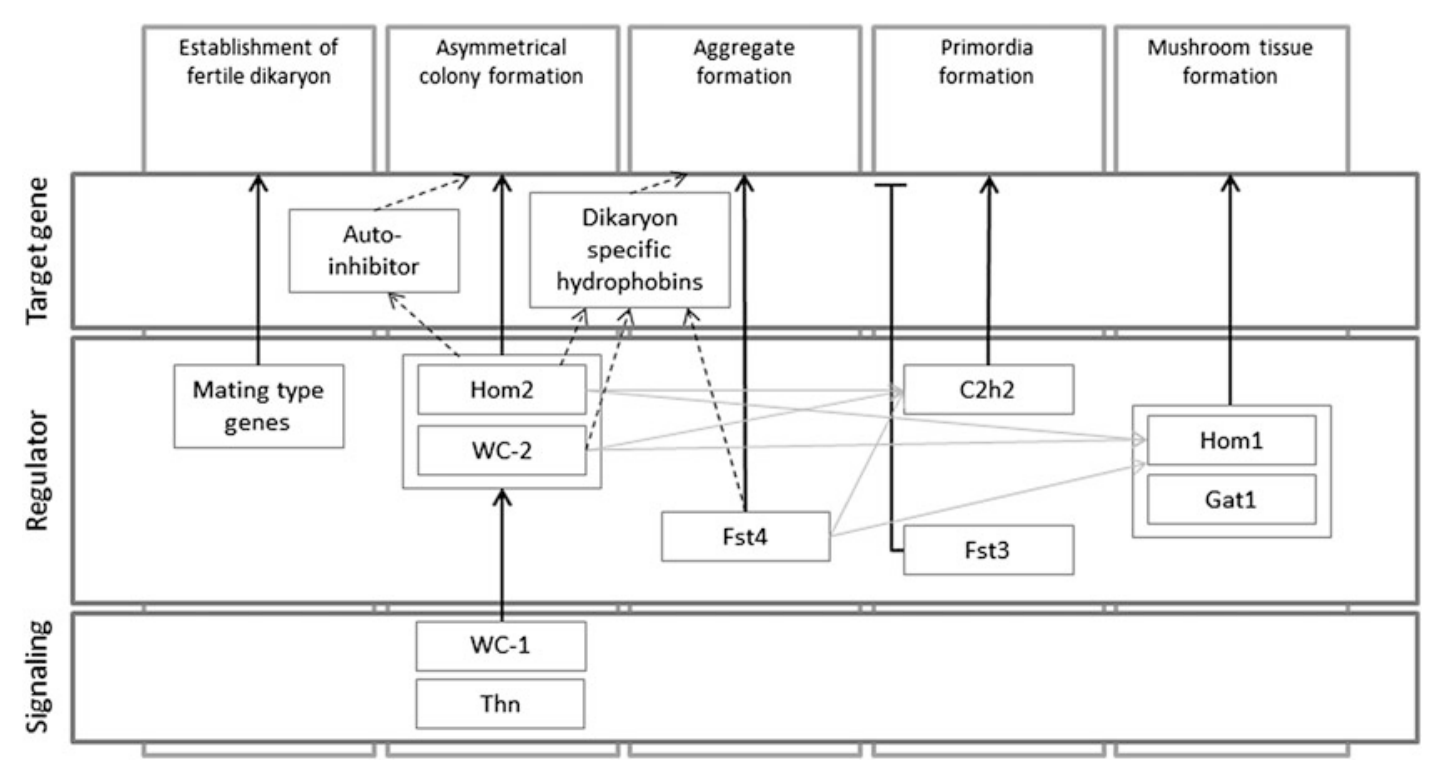

Fig. 15.2 Model of regulation of fruiting body formation in S. commune. Depicted are transcription factors and proteins involved in signalling as have been investigated in S. commune. Thick lines represent developmental stages in which these genes are involved. Thin

cetes. The homokaryon of Agaricus bitorquis is multikaryotic, while the fertile heterokaryon is dikaryotic but without clamp connections (Raper 1976). The fertile heterokaryon of $A$. bisporus grows directly from a basidiospore that contains two nuclei with different mating types. The heterokaryon is multikaryotic and, like A. bitorquis, has no clamp connections (Raper et al. 1972).

The mating-type genes are the master regulators of sexual development (see also Freihorst et al. 2016). When two homokaryons with different alleles for the $A$ and $B$ matingtype loci (in $S$. commune called MATA and $M A T B)$ fuse, a heterokaryon is formed with the potential to fruit. Nuclei that are exchanged migrate to the apical compartment of the recipient hypha, which is accompanied by septal dissolution. In the apical compartment, the donated and recipient nuclei pair and hyphal dissolution is switched off. In fact, new septa are formed that are more resistant to dissolution and which physically prevent nuclear migration (Wessels and Marchant 1974). The nuclei in a dikaryotic hyphal compartment divide synchronously. Nuclear division is lines represent interaction between transcription factors, as indicated by whole genome expression analysis (Ohm et al. 2011, 2013). Dotted lines represent regulation of target genes that are involved in specific stages of development

accompanied by the formation of clamps. As a result, the apical and the subapical compartments contain nuclei of both mating types.

The molecular structure of the mating-type loci has been uncovered in, for instance, S. commune and $C$. cinereus (for a detailed overview and references, see Dyer et al. 2016). The $A$ genes of these fungi encode homeodomain proteins of the HD1 and HD2 type. In heterokaryons with nuclei containing different $A$ genes, these proteins form heterodimers that are active in clamp development and the initial pairing and migration of compatible nuclei. On the other hand, the $B$ genes of $C$. cinereus and $S$. commune encode pheromones and G-coupled pheromone receptors. In heterokaryons with nuclei containing different $B$ genes, pheromones from one nucleus interact with receptors encoded by the other nucleus and vice versa. These genes are involved in exchange and migration of the nuclei as well as fusion of the hook cell. Homokaryotic mutant strains have been isolated with a constitutive active $A$ mating-type gene (referred to as $M A T A^{\text {con }}$ in S. commune, Amut in C. cinereus) and/or $B$ mating-type gene (referred to as $M A T B^{\text {con }}$ in S. commune, Bmut in C. cinereus) 
(Raper et al. 1965; Koltin 1970; Swamy et al. 1984). Activity of these loci is thus independent of a compatible allele donated by a sexual partner. The S. commune MATA ${ }^{\text {con }} M A T B^{\text {con }}$ dikaryotic homokaryon can form fruiting bodies. Likewise, AmutBmut homokaryons of C. cinereus form fruiting bodies like wild-type dikaryons (Swamy et al. 1984; Boulianne et al. 2000). Mutations in the $p c c 1$ gene of $C$. cinereus can also lead to fruiting in homokaryons (Uno and Ishikawa 1971; Muraguchi et al. 1999). The product of $p c c 1$ has been proposed to be a negative regulator of the $A$ mating-type pathway (Kamada 2002; see below). The frt 1 gene of $S$. commune also initiates fruiting in a homokaryon. Certain homokaryons with introduced copies of this gene start to fruit independent of the mating-type loci (see next section).

S. commune and C. cinereus are examples of tetrapolar species that have two unlinked mating-type loci. Bipolar species exist within the agaricomycetes as well, where the $B$ locus has lost its ability to distinguish self from nonself (James et al. 2006). This is in contrast to bipolar basidiomycetes that have linked all mating-type genes on a single locus (Bakkeren and Kronstad 1994; Lengerer et al. 2002).

\section{Other Regulatory Genes}

Regulatory Genes in Establishment of the Dikaryotic Mycelium

Establishment of the dikaryotic mycelium strongly impacts gene expression. For instance, $26 \%$ of the genes of $S$. commune show a fold change of two or more upon mating (Erdmann et al. 2012). The $A$ and $B$ pathways regulate $27 \%$ and $42 \%$ of these genes, respectively, while the remaining $31 \%$ are controlled by both mating-type loci. Among the $A$-activated genes is $c l p 3$, a homologue of $c l p 1$ in $C$. cinereus (Inada et al. 2001). The latter gene was isolated by complementation of an AmutBmut mutant homokaryon that did not form clamps. Expression of $c l p 1$ also depends on the $A$ genes. Clamps are made independently from the homeodomain heterodimer when $\operatorname{clp} 1$ is expressed from a constitutive promoter. The mode of action of Clp1 is not known, and it does not contain any known structural motifs. Gene pcc1 (see previous section) is another gene that seems to be part of the $A$-regulated pathway (Murata et al. 1998). A homokaryotic strain with a mutated copy of this gene forms pseudoclamps, and it has the capacity to form fully differentiated fruiting bodies. These data and its expression in a wild-type homokaryon indicate that $p c c 1$ is a repressor of the fruiting pathway in the absence of a functional $A$ complex (i.e. in the homokaryon). Gene $p c c 1$ likely encodes a transcription factor because of its HMG box motif and nuclear localisation signal. The presence of pheromone-responsive elements in the $p c c 1$ promoter suggests that it is a pheromone-responsive gene. Indeed, it is upregulated by a compatible $B$-mating interaction (Murata et al. 1998). The fact that $p c c 1$ is also upregulated by an activated $A$ gene suggests that Pccl coordinates the activities of the $A$ and $B$ genes (Murata et al. 1998). This hypothesis is supported by the finding that the pcc1 mutant homokaryon has the potential to form fruiting bodies. It has been suggested that the repressor activity of $p c c 1$ is released by a compatible $A$ gene interaction via $c l p 1$ (Kamada 2002).

FRT1 is a putative nucleotide-binding protein with a P-loop motif (Horton and Raper 1995). Its gene was identified by its fruiting phenotype when transformed into certain homokaryons of S. commune (Horton and Raper 1991). Experimental evidence indicates that homokaryotic strains that start to fruit have an endogenous frt 1 allele of a different kind (designated frt1-2; Horton et al. 1999). In contrast, strains possessing frt1-1 do not fruit when transformed with this allele (Horton and Raper 1991). Homokaryons in which the frt 1 gene is disrupted are more fluffy compared to wild-type strains, and the $\Delta f r t 1$ aerial hyphae aggregate (Horton et al. 1999) as observed during the first stages of fruiting body development (Raudaskoski and Vauras 1982; van der Valk and Marchant 1978). This is accompanied by increased expression of the dikaryon-specific genes sc 1 and sc4 (see Sect. IV). From these data, it was proposed that FRT1 is part of a signal transduction pathway that represses expression of dikaryon-specific genes 
in the monokaryon (Horton and Raper 1995). However, the absence of FRT1 is not sufficient to initiate full development of fruiting bodies. How can haploid fruiting be explained when frt1-1 is transformed into a frt1-2 strain? It has been proposed that these proteins dimerise and by this relieve repression of the dikaryon-specific genes. The heterodimer would also activate genes, resulting in the formation of mature fruiting bodies (Horton et al. 1999). Note that the absence of frt 1 did not affect fruiting in the dikaryon (Horton et al. 1999). This suggests that frt1 is not a component of the pathway that leads to formation of fruiting bodies in the dikaryon.

Highly conserved small $G$ proteins, called Ras, play an essential role in intracellular signalling (e.g. the MAPK, cAMP and Cdc42 signalling pathways). Two ras genes have been identified in nearly all fungi. The Ras protein exists in a GTP-bound active form and a GDPbound inactive form. Guanine nucleotide exchange factors (GEFs) and GTPase-activating proteins (GAPs) promote interconversion of the active and inactive forms of Ras, respectively. Deletion of gap1 of $S$. commune resulted in hampered clamp, gill and spore formation (Schubert et al. 2006). Constitutively activated Ras1 resulted in dysfunctional dikaryotization, as nonself nuclei were not accepted. Furthermore, growth orientation, branching, fruiting body morphology and spore formation were affected (Knabe et al. 2013). Since deletion of gap1 increases Ras1 activity, an overlap of phenotypical traits with the ras 1 overexpression strain is expected. Indeed, PKA levels were increased in both strains, linking these proteins to the CAMP signalling pathway. Expression analysis of above-mentioned transformant strains and a constitutively active $\mathrm{Cdc} 42$ mutant, involved in the MAPK pathway, revealed an overlap in target genes. This implies that Ras1 is also involved in MAPK signalling in S. commune (Weber et al. 2005).

\section{Regulatory Genes Involved in Fruiting Body For- mation in the Heterokaryon}

The thn 1 gene of $S$. commune acts early in the developmental pathway of fruiting body formation. A mutation in thn1 leads to pleiotropic effects including the absence of aerial growth in the homokaryon and, when homozygous, in the dikaryon (Raper and Miles 1958; Schwalb and Miles 1967; Wessels et al. 1991b). Thus, both aerial hyphae and fruiting body formation are affected. Thn1 is a putative Regulator of Gprotein signaling protein that interacts with a $\mathrm{G} \alpha$ subunit of a heterotrimeric $\mathrm{G}$ protein. Such a protein converts an active GTP-bound G $\alpha$ subunit into an inactive GDP-bound G $\alpha$. It was therefore proposed (Fowler and Mitton 2000) that $t h n 1$ regulates a heterotrimeric $G$ protein signalling pathway that functions in the decision of the vegetative mycelium to start the development of aerial hyphae and fruiting bodies. This function would be similar to that of FlbA in A. nidulans (Lee and Adams 1994). Transcriptome analysis of a thn mutant showed 114 genes, mostly involved in cellular responses that were affected by the mutation. This is in agreement with a role in $G$ protein signalling (Erdmann et al. 2012). Most of the pleiotropic effects of the thn mutation are overcome by growing the mutant near a wild-type colony (Schuren 1999). A diffusible molecule smaller than $8 \mathrm{kDa}$ would be responsible for this effect and may be part of the signalling cascade.

A set of transcription factor genes has been identified that is involved in different stages of fruiting body development in S. commune (Fig. 15.2) (Ohm et al. 2010, 2011, 2013). Inactivation of the homeodomain gene hom 2 results in symmetrical monokaryon-like colonies that form aerial hyphae but do not form aggregates, primordia and mature fruiting bodies. Fst 4 is a zinc finger transcription factor positioned downstream of Hom2. Deletion of its encoding gene results in irregular dikaryon-like colonies that form aerial hyphae but do not form aggregates. Zinc finger protein $\mathrm{C} 2 \mathrm{~h} 2$ is involved in primordia formation. Inactivation of its encoding gene gives rise to irregular colonies that form aerial hyphae and aggregates. Deletion strains of fst3, gat 1 and hom 1 do form fruiting bodies. However, these fruiting bodies are smaller and are produced in a higher number. It was proposed that Fst3, a fungal-specific transcription factor, is a local repressor of primordia formation (Ohm et al. 2010). This would imply the existence of communication 
between developing fruiting bodies. Such communication would ensure full outgrowth of mushrooms when resources are limited. Gat1, a GATA-type zinc finger protein, and Hom1, a homeodomain protein, might play a role in the expansion of the fruiting body. Expansion of fruiting bodies will go at the expense of outgrowth of neighbouring aggregates because of limited resources. Such a mechanism would not require communication between fruiting bodies. The ich 1 gene of $C$. cinereus also acts at later stages of fruiting body formation. Cap differentiation is blocked at an early stage of fruiting body differentiation in the ich1 mutant (Muraguchi and Kamada 1998). In contrast to wildtype primordia, no rudimentary pileus is observed in the primordial shaft of the ich1 mutant. The precise role of the gene is not yet known. It encodes a protein that contains a nuclear targeting signal and an S-adenosyl-Lmethionine (SAM)-binding motif (Kües 2000), being characteristic for the enzyme family of methyltransferases (Faumann et al. 1999).

The model presented in Fig. 15.2 could also apply to other mushroom-forming fungi. The hom 2 , hom 1, fst $3, f s t 4, c 2 h 2$ and gat 1 genes are basidiomycete-specific regulators (Todd et al. 2014). These and the other S. commune transcription factors that are involved in fruiting body development have homologues in Laccaria bicolor and in A. bisporus (Ohm et al. 2010; Morin et al. 2012). Similarly, homologues of ich1 are present in S. commune and A. bisporus. Gene expression analysis of $A$. bisporus revealed 22 genes with homologues in $S$. commune that were significantly upregulated in mature fruiting bodies. This group includes $f s t 3, f s t 4, c 2 h 2$ and hom1. Similarly, homologues of hom 2, fst4, fst3, gat1 and hom 1 showed similar expression in L. bicolor (Morin et al. 2012), while homologues of $c 2 h 2$, fst 3 , hom 1 and gat 1 showed similar expression in $C$. cinereus (Plaza et al. 2014).

Whole genome expression analysis revealed that 284 genes are differentially expressed in the monokaryotic stage of $S$. commune (Ohm et al. 2010), whereas 128 genes are differentially expressed during the aggregate stage. Genes involved in hydrophobins, protein and energy production are upregulated during aggregation, while genes involved in signal transduction, gene regulation, carbohydrate metabolism and cell wall biogenesis are downregulated. 467 genes were differentially expressed during primordia formation. Upregulated genes are involved in signal transduction, gene regulation, carbohydrate metabolism and cell wall biogenesis. Protein and energy production are downregulated. Of the 128 differentially expressed genes during fruiting body maturation, fatty acid metabolism is upregulated, while gene regulation and glucose, alcohol and amino acid metabolism are downregulated (Ohm et al. 2010). The high number of genes exclusively expressed during primordia development suggests this is a crucial developmental switch.

\section{Nuclear Positioning}

The sc1, sc4 and sc6 hydrophobin genes (see Sect. IV.A) as well as $s c 7$ and $s c 14$ are expressed in dikaryons (MATA-on MATB-on) of S. commune but not in monokaryons (MATA-off MATB-off) and MATA-on MATB-off or MATAoff $M A T B$-on mycelia (Mulder and Wessels 1986; Wessels et al. 1995). In contrast, the $s c 3$ hydrophobin gene is active in the monokaryon and is downregulated in a MATA-off MATB-on mycelium (Ásgeirsdóttir et al. 1995). From this, it is expected that $s c 3$ would also be inactive in dikaryons (i.e. MATA-on MATB-on). Indeed, sc3 mRNA levels are reduced in a fruiting dikaryon. However, under non-fruiting conditions (e.g. high $\mathrm{CO}_{2}$ and darkness), high $s c 3$ expression is observed, while expression of $s c 1, s c 4, s c 6, s c 7$ and $s c 14$ is relatively low (Wessels et al. 1987). Apparently, the MATB pathway, and possibly also the MATA pathway, is not active in at least part of the dikaryotic mycelium. This was explained by a regulatory mechanism that varies the distance between the nuclei in compartments of dikaryotic hyphae (Schuurs et al. 1998). The distance of nuclei in dikaryotic aerial hyphae is relatively large $(>8 \mu \mathrm{m})$ and correlates with high sc3 expression. In contrast, nuclear distance in fruiting bodies is small $(<2 \mu \mathrm{m})$, correlating with low $s c 3$ and high $s c 4$ expression. Increased distance of the nuclei $(>4 \mu \mathrm{m})$ would inactivate 
the $M A T B$-on pathway, and possibly also the MATA-on pathway, resulting in a monokaryonlike gene expression (Wessels et al. 1998).

\section{Structural Proteins and Enzymes Involved in Fruiting}

\section{A. Hydrophobins}

Hydrophobins are secreted proteins that fulfil a wide spectrum of functions in fungal growth and development (Wessels 1997; Wösten and Wessels 1997; Wösten 2001, see Chap. 7 in Volume VIII, The Mycota). Class I and class II hydrophobins are distinguished based on hydropathy patterns and solubility characteristics (Wessels 1994). Basidiomycetes only have class I hydrophobins. These hydrophobins can affect hyphal wall composition in a soluble state (van Wetter et al. 2000b). However, most functions of these hydrophobins are based on their property to self-assemble into an amphipathic membrane at hydrophilic/hydrophobic interfaces (Wösten et al. 1993, 1994a, b, 1995, 1999). This $\sim 10 \mathrm{~nm}$ thick membrane is highly insoluble and consists of a mosaic of amyloidlike fibrils called rodlets (Wösten et al. 1993; Wösten and de Vocht 2000; de Vocht et al. 2002; Butko et al. 2001; Scholtmeijer et al. 2009). Upon self-assembly at the interface between the hydrophilic cell wall and a hydrophobic environment (the air or the hydrophobic surface of a host), the hydrophilic side of the amphipathic membrane will face the cell wall, while the hydrophobic side becomes exposed. Aerial hyphae and spores thus become hydrophobic, while hyphae that grow over a hydrophobic substrate become attached.

The role of hydrophobins in mushroomforming fungi has been best studied in S. commune. This fungus contains 13 hydrophobin genes (Ohm et al. 2010) including $s c 1, s c 3, s c 4$ and sc6 (Mulder and Wessels 1986; Schuren and Wessels 1990; Wessels et al. 1995; de Vocht et al. 1998). The sc1, sc4 and sc6 hydrophobin genes are dikaryon-specific and are regulated by the mating-type genes (Ruiters et al. 1988), fbf (Springer and Wessels 1989), thn (Wessels et al. 1991b) and transcriptional regulators involved in pre-aggregate development $w c-2$, hom 2 and fst4 (Ohm et al. 2011, 2013). On the other hand, $s c 3$ is expressed both in the monokaryon and the dikaryon (see Sect. III.D). It is regulated by $t h n, w c-2$, hom 2 and $f s t 4$ but not by $f b f$. Hydrophobins make up 6-8 \% of protein synthesised by $S$. commune at the time of emergent growth (Wessels et al. 1991a, b). So far, the roles of SC3 and SC4 have been established and they will be discussed below.

Expression of $s c 3$ in monokaryons is induced after a feeding mycelium has been established (Mulder and Wessels 1986). SC3 secreted by submerged hyphae self-assembles at the medium-air interface, which is accompanied by a huge drop in water surface tension. This enables hyphae to breach the interface of the aqueous environment and the air to form aerial hyphae (Wösten et al. 1999). The water surface tension remains high in a $\Delta s c 3$ strain and only few hyphae can escape the aqueous environment. In other words, in the absence of sc3 expression, hyphae are forced to grow in the aqueous substrate. Expression of $s c 3$ is thus a main event in the onset of aerial growth. How the mycelium senses that the feeding mycelium is large enough to be able to support aerial growth by switching on SC3 production remains to be solved (Wösten and Willey 2000). SC3 secreted by aerial hyphae cannot diffuse into the medium but will be confronted with the cell wall-air interface. As a result, SC3 assembles at the surface of these hyphae making them hydrophobic (Wösten et al. 1994a). SC3 also lowers the water surface tension in the dikaryon allowing aerial hyphae to grow into the air (van Wetter et al. 2000a). The amount of SC4 in the medium is too low to complement for the absence of SC3 in a $\Delta s c 3 \Delta s c 3$ dikaryon. SC3 also coats aerial hyphae of the dikaryon and hyphae at the outer surface of fruiting bodies (Ásgeirsdóttir et al. 1995). SC4, but not SC3, is located in the fruiting body context, in which it lines air channels that traverse the plectenchyma (Lugones et al. 1999). The air channels of $\Delta s c 4 \Delta s c 4$ fruiting bodies readily fill with water in the absence of a hydrophobic coating (van Wetter et al. 2000a). SC4 thus ensures gas exchange in the fruiting body tissue under moist conditions. 
The ABH1 hydrophobin of A. bisporus (Lugones et al. 1996; de Groot et al. 1996) is an orthologue of SC4 of S. commune. Expression of $a b h 1$ starts prior to primordia formation and remains high during primordia and fruiting body formation (Eastwood et al. 2013). The protein not only lines air channels in the fruiting body tissue (Lugones et al. 1999) but also coats the outer surface of the mushroom (Lugones et al. 1996). The HypB hydrophobin of A. bisporus is located at the border of the cap and the stipe tissue and has been proposed to protect the mushroom against bacterial infection (de Groot et al. 1999).

The presence of multiple hydrophobin genes not only enables the fungus to produce hydrophobins at different stages of development (Kershaw et al. 1998) but also to form hydrophobins that are tailored to fulfil specific functions (van Wetter et al. 2000a). SC4 can substitute for SC3 in the formation of hydrophobic aerial hyphae, but hyphal attachment to hydrophobic surfaces is only partially restored. This is explained by a lower affinity of assembled SC4 for the cell wall of adhering hyphae when compared to SC3. Possibly, this is related to sugar-binding specificities of these hydrophobins (van Wetter et al. 2000a). The exposed carbohydrates of cell walls of aerial hyphae and hyphae in the fruiting body tissue may be different, requiring different lectin specificities to ensure strong binding to the cell wall. Evolution of hydrophobins to fulfil specific functions is also indicated by sequence analysis. SC3 of $S$. commune (de Vocht et al. 1998), ABH3 of $A$. bisporus (Lugones et al. 1998), COH1 of $C$. cinereus (Ásgeirsdóttir et al. 1997) and POH1 of P. ostreatus (Ásgeirsdóttir et al. 1998) that all function in the formation of aerial hyphae are more related to each other than $\mathrm{SC} 3$ and $\mathrm{ABH} 3$ to other hydrophobins of $S$. commune and $A$. bisporus, respectively. Similarly, the fruiting body-specific hydrophobins of $S$. commune cluster with $H y p B$ (de Groot et al. 1999), $A B H 1$ and $A B H 2$ (Lugones et al. 1996; de Groot et al. 1996) of $A$. bisporus.

With the established roles of SC3, SC4 and $\mathrm{ABH} 1$, we are only at the beginning of our understanding of the functions of hydrophobins in fruiting. Dikaryons express several hydrophobins at the same time that may have specific properties and/or are expressed at a particular place. For instance, it has been suggested that hydrophobins could be involved in aggregating aerial hyphae during fruiting body morphogenesis (see Chap. 21 in Volume I 1994). The situation is even more complex by the presence of proteins that can substitute for hydrophobins. For example, the SC15 protein can partly rescue the reduction of surface tension of the culture medium by SC3 (Lugones et al. 2004).

\section{B. Lectins}

Lectins are carbohydrate-binding proteins that play diverse roles in fungi (Singh et al. 2010). For instance, they function in parasitism against plants and insects, in predation of soil nematodes and in early stages of ectomycorrhizal symbiosis. Expression of galectin lectins is upregulated in multiple stages of fruiting in $C$. cinereus and Agrocybe aegerita (Boulianne et al. 2000; Luan et al. 2010). They may play a role in mushroom defence against predators and parasites but also seem to play a role in mushroom development. Addition of the galectin AAL of A. aegerita to an established mycelium induces aggregation and primordia formation both in A. aegerita and Auricularia polytricha (Sun et al. 2003; Luan et al. 2010). In contrast, the presence of the galectin at the moment of inoculation results in growth inhibition and repression of fruiting (Luan et al. 2010). These data show that temporal expression of galectins is important for their role in mushroom development.

\section{Haemolysins}

Haemolysins are pore-forming proteins that are known for their ability to lyse red blood cells. Aggregation of haemolysins in the plasma membrane results in $\sim 4 \mathrm{~nm}$ wide pores that permeabilise the membrane (Nayak et al. 2013). Fungal homologues have been identified in the basidiomycetes $A$. aegerita (Fernandez Espinar and Labarère 1997; Berne et al. 2002), 
P. ostreatus (Berne et al. 2002) and S. commune (Han et al. 2010). There is a strong evidence for the involvement of haemolysins in fruiting body formation. These proteins are specifically expressed in primordia and young fruiting bodies of $A$. aegerita and $P$. ostreatus (Vidic et al. 2005). In both species, the concentration of protein is highest at the edge of lamellae, in basidia and in developing basidiospores. Notably, external addition of the haemolysin ostreolysin of $P$. ostreatus to mycelium boosts fruiting initiation in this fungus and increases quantity and size of fruiting bodies (Berne et al. 2007).

\section{Oxidative Enzymes}

A role for laccases in oxidative cross-linking of hyphae in polypores, which become pigmented and woody by oxidation of phenolic compounds, was already proposed in 1967 (Bu'Lock 1967; Bu'Lock and Walker 1967). However, so far, proof of a role in mushroom development is lacking. Evidence for a role of cytochrome P450 enzymes in fruiting body formation is available. The eln2-1 mutant of $C$. cinereus was isolated in a screen for developmental mutants (Muraguchi et al. 1999). This mutant is characterised by dumpy fruiting body primordia. Cell morphogenesis and tissue organisation are affected in the primordial shaft of the eln2-1 mutant. As a result, the mature fruiting bodies have short stipes (Muraguchi and Kamada 2000). The $\ln 2$ gene is constitutively expressed and encodes a novel type of cytochrome P450 enzyme. These enzymes are involved in the oxidative, peroxidative and reductive metabolism of numerous compounds. A deletion of 18 amino acids at the C-terminus is the cause of the mutant phenotype. Muraguchi and Kamada (2000) gave three explanations to explain the mutant phenotype. A changed catalytic activity may produce a toxic compound that affects development in the primordial shaft. Alternatively, activity of the truncated enzyme may not result in a product that is normally instrumental in development. Finally, the mutant enzyme may overproduce a normal metabolite or produce superoxide radicals.

\section{E. Expansins}

Expansins are nonenzymatic proteins that induce cell wall extension and cell wall modification (McQueen-Mason et al. 1992; Cosgrove 2005). These proteins are believed to act by disrupting non-covalent interactions between carbohydrate polymers (McQueen-Mason and Cosgrove 1995). Expansins were originally found in plants, but homologues have also been identified in fungi. Basidiomycetes do not appear to have strict homologues of expansins. Instead, they have expansin-like proteins named loosenins with an N-terminal domain similar to that of plant expansins. LOOS1 was first isolated from the basidiomycete Bjerkandera adusta (QuirozCastañeda et al. 2011), but they also occur in, for instance, S. commune, A. bisporus, C. cinereus and L. bicolor (Suzuki et al. 2014). The main function of expansin(-like) proteins in fungi is believed to facilitate degradation of plantderived substrates. However, evidence accumulates that these proteins also play a role in morphogenesis and cell wall modification. Deletion of the expansin-like gene eglD in A. nidulans results in increased resistance against lysing enzymes. This observation combined with the exclusive presence of EglD in conidial cell walls suggests that this protein is involved in cell wall remodelling during germination (Bouzeralou et al. 2008). In basidiomycetes, repression of stipe wall extension by heat in F. velutipes and C. cinereus could be rescued by a snail expansinlike protein (Fang et al. 2014; Zhang et al. 2014). This suggests that expansin(-like) proteins are involved in the extension of fruiting bodies.

\section{Conclusions}

Establishment of the dikaryotic mycelium and formation of fruiting bodies are highly complex developmental programmes that are activated by a combination of environmental cues. A wide variety of proteins are expected to regulate and coordinate these programmes or to fulfil enzymatic conversions or structural roles. With the identification of the first genes involved in mushroom development, we are only at the beginning of understanding fruiting body for- 
mation. The process of identification of genes will be accelerated by whole genome expression studies and increased availability of molecular tools to assign functions to genes.

Establishment of the dikaryon and emergence of fruiting bodies in basidiomycetes are regulated by the mating-type genes. These genes encode DNA-binding proteins and pheromones and their receptors. Regulation of fruiting by the mating-type genes is mediated by downstream transcription factors. Several genes encoding such regulatory proteins have now been identified. Regulatory circuits ultimately activate genes encoding structural proteins or enzymes that are involved in fruiting body formation. The role of hydrophobins is well established. They enable hyphae to escape the aqueous environment to allow fruiting body development. Moreover, they coat aerial structures and line air channels in mushrooms. The hydrophobic coating irreversibly directs growth of hyphae into the air, allows dispersal of spores and ensures gas exchange in fruiting bodies under humid conditions. Apart from hydrophobins, phenolics polymerised by the action of laccases may contribute to surface hydrophobicity of fruiting bodies. These enzymes have also been proposed to crosslink cell walls of hyphae in the fruiting bodies but this still has to be established. Experimental evidence indicates that cytochrome P450 enzymes, lectins, haemolysins and expansins also function in mushroom development. Lectins may be involved in aggregation of hyphae, haemolysins in signalling particularly to induce apoptosis of selected hyphae in the fruiting body, while expansins may be involved in cell wall modification and extension.

\section{References}

Ásgeirsdóttir SA, van Wetter MA, Wessels JGH (1995) Differential expression of genes under control of the mating-type genes in the secondary mycelium of Schizophyllum commune. Microbiology 141:1281-1288

Ásgeirsdóttir SA, Halsall JR, Casselton LA (1997) Expression of two closely linked hydrophobin genes of Coprinus cinereus is monokaryon-specific and down-regulated by the oid-1 mutation. Fungal Genet Biol 22:54-63
Ásgeirsdóttir SA, de Vries OMH, Wessels JGH (1998) Identification of three differentially expressed hydrophobins in Pleurotus ostreatus (oyster mushroom). Microbiology 144:2961-2969

Bahn YS, Muhlschlegel FA (2006) $\mathrm{CO}_{2}$ sensing in fungi and beyond. Curr Opin Microbiol 9:572-578

Bakkeren G, Kronstad JW (1994) Linkage of matingtype loci distinguishes bipolar from tetrapolar mating in basidiomycetous smut fungi. Proc Natl Acad Sci USA 91:7085-7089

Bayram Ö, Biesemann C, Krappmann S, Galland P, Braus GH (2008a) More than a repair enzyme: Aspergillus nidulans photolyase-like CryA is a regulator of sexual development. Mol Biol Cell 19:3254-3262

Bayram O, Krappmann S, Ni M, Bok JW, Helmstaedt K, Valerius O, Braus-Stromeyer S, Kwon NJ, Keller NP, Yu JH, Braus GH (2008b) VelB/VeA/LaeA complex coordinates light signal with fungal development and secondary metabolism. Science 320:1504-1506

Bayram Ö, Braus GH, Fischer R, Rodriguez-Romero J (2010) Spotlight on Aspergillus nidulans photosensory systems. Fungal Genet Biol 47:900-908

Berne S, Križaj I, Pohleven F, Turk T, Maček P, Sepčić K (2002) Pleurotus and Agrocybe hemolysins, new proteins hypothetically involved in fungal fruiting. Biochem Biophys Acta 1570:153-159

Berne S, Pohleven J, Vidic I, Rebolj K, Pohleven F, Turk T, Maček P, Sonnenberg A, Sepčić K (2007) Ostreolysin enhances fruiting initiation in the oyster mushroom (Pleurotus ostreatus). Mycol Res 111(12):1431-1436

Blumenstein A, Vienken K, Tasler R, Purschwitz J, Veith D, Frankenberg-Dinkel N, Fischer R (2005) The Aspergillus nidulans phytochrome FphA represses sexual development in red light. Curr Biol 15:1833-1838

Boulianne RP, Liu Y, Aebi M, Lu BC, Kües U (2000) Fruiting body development in Coprinus cinereus: regulated expression of two galectins secreted by a non classical pathway. Microbiology 146:1841-1853

Bouzeralou D, Billini M, Roumelioti K, Sophianopoulou V (2008) EglD, a putative endoglucanase, with an expansin like domain is localized in the conidial cell wall of Aspergillus nidulans. Fungal Genet Biol 45:839-850

Bu'Lock JD (1967) Essays in biosynthesis and microbial development. In: Squibb ER (ed) Essays in biosynthesis and microbial development, lectures on chemistry and microbial products. Wiley, New York, pp 1-18

Bu'Lock JD, Walker DC (1967) On chagi. J Chem Soc Sect C 5:336-338

Butko P, Buford JP, Goodwin JS, Stroud PA, McCormick CL, Cannon GC (2001) Spectroscopic evidence for amyloid-like interfacial self-assembly of hydrophobin Sc3. Biochem Biophys Res Commun 280:212-215

Chiu S-W, Moore D (eds) (1996) Patterns in fungal development. Cambridge University Press, Cambridge 
Clémonçon H (1997) Anatomy of the hymenomycetes. An introduction to the cytology and plectology of crust fungi, bracket fungi, club fungi, Chantarelles, Agarics and Boletes. F. Flück-Wirth, Teufen, Switzerland

Cosgrove DJ (2005) Growth of the plant cell wall. Nat Rev Mol Cell Biol 6(11):850-861

de Groot PWJ, Schaap PJ, Sonnenberg ASM, Visser J, Van Griensven LJLD (1996) The Agaricus bisporus hypA gene encodes a hydrophobin and specifically accumulates in peel tissue of mushroom caps during fruit body development. J Mol Biol 257:10081018

de Groot PWJ, Roeven RT, Van Griensven LJ, Visser J, Schaap PJ (1999) Different temporal and spatial expression of two hydrophobin-encoding genes of the edible mushroom Agaricus bisporus. Microbiology 145:1105-1113

de Vocht ML, Scholtmeijer K, van der Vegte EW, de Vries OMH, Sonveaux N, Wösten HAB, Ruysschaert J-M, Hadziioannou G, Wessels JGH, Robillard GT (1998) Structural characterization of the hydrophobin SC3, as a monomer and after selfassembly at hydrophobic/hydrophilic interfaces. Biophys J 74:2059-2068

de Vocht ML, Reviakine I, Ulrich WP, Bergsma-Schutter W, Wösten HAB, Vogel H, Brisson A, Wessels JGH, Robillard GT (2002) Self-assembly of the hydrophobin SC3 proceeds via two structural intermediates. Protein Sci 11:1199-1205

Durand R (1985) Blue U.V.-light photoreception in fungi. Rev Physiol Végét 23:935-943

Dyer PS, Inderbitzin P, Debuchy R (2016) Mating-type structure, function, regulation and evolution in the pezizomycotina. In: Wendland J (ed) Growth, differentiation and sexuality. Springer, Cham, pp 351-385

Eastwood DC, Herman B, Noble R, DobrovinPennington A, Sreenivasaprasad S, Burton KS (2013) Environmental regulation of reproductive phase change in Agaricus bisporus by 1-octen-3-ol, temperature and CO2. Fungal Genet Biol 55:54-66

Erdmann S, Freihorst D, Raudaskoski M, SchmidtHeck W, Jung EM, Senftleben D, Kothe E (2012) Transcriptome and functional analysis of mating in the basidiomycete Schizophyllum commune. Eukaryot Cell 11:571-589

Fang H, Zhang W, Niu X, Liu Z, Lu C, Wei H, Yuan S (2014) Stipe wall extension of Flammulina velutipes could be induced by an expansin-like protein from Helix aspersa. Fungal Biol 118(1):1-11

Faumann EB, Blumenthal RM, Cheng XD (1999) Structure and evolution of AdoMet-dependent methyltransferases. In: Cheng XD, Blumenthal RM (eds) S-adenosylmethionine-dependent methyltransferases: structures and functions. World Scientific, Singapore, pp 1-38

Fernandez Espinar MT, Labarère J (1997) Cloning and sequencing of the Aa-pril gene specifically expressed during fruiting initiation in the edible mushroom Agrocybe aegerita. Curr Genet 32:420-424
Fowler TJ, Mitton MF (2000) Scooter, a new active transposon in Schizophyllum commune, has disrupted two genes regulating signal transduction. Genetics 156:1585-1594

Freihorst D, Fowler TJ, Bartholomew K, Marjatta R, Stephen Horton J, Kothe E (2016) The mating type genes of the basidiomycetes. In: Wendland J (ed) Growth, differentiation and sexuality. Springer, Cham, pp 329-349

Grillo R, Korhonen K, Hantula J, Hietala AM (2000) Genetic evidence of somatic haploidization in developing fruit bodies of Armillaria tabescens. Fungal Genet Biol 30:135-145

Han C-H, Zhang G-Q, Wang H-X, Ng TB (2010) Schizolysin, a hemolysin from the split gill mushroom Schizophyllum commune. FEMS Microbiol Lett 309(2):115-121

Horton JS, Raper CA (1991) A mushroom-inducing DNA sequence isolated from the basidiomycete Schizophyllum commune. Genetics 129:707-716

Horton JS, Raper CA (1995) The mushroom-inducing gene FRT1 of Schizophyllum commune encodes a putative nucleotide binding protein. Mol Gen Genet 247:358-366

Horton JS, Palmer GE, Smith WJ (1999) Regulation of dikaryon-expressed genes by FRT1 in the basidiomycete Schizophyllum commune. Fungal Genet Biol 26:33-47

Inada K, Morimoto Y, Arima T, Murata Y, Kamada T (2001) The clp1 gene of the mushroom Coprinus cinereus is essential for $A$-regulated sexual development. Genetics 157:133-140

Ishikawa H (1967) Physiological and ecological studies on Lentinus edodes (Berk.) Sing. J Agric Lab 8:157

James TY, Srivilai P, Kües U, Vilgalys R (2006) Evolution of the bipolar mating system of the mushroom Coprinellus disseminatus from its tetrapolar ancestors involves loss of mating-typespecific pheromone receptor function. Genetics 172(3):1877-1891

Jennings DH (1984) Water flow through mycelia. In: Jennings DH, Rayner ADM (eds) The ecology and physiology of fungal mycelia. Cambridge University Press, Cambridge, pp 143-164

Kamada T (2002) Molecular genetics of sexual development in the mushroom Coprinus cinereus. BioEssays 24:449-459

Kamada T, Kurita R, Takemaru T (1978) Effects of light on basidiocarp maturation in Coprinus macrorhizus. Plant Cell Physiol 19:263-275

Kamada T, Sano H, Nakazawa T, Nakahori K (2010) Regulation of fruiting body photomorphogenesis in Coprinopsis cinerea. Fungal Genet Biol 47:917921

Kershaw MJ, Wakley G, Talbot NJ (1998) Complementation of the mpg1 mutant phenotype in Magnaporthe grisea reveals functional relationships between fungal hydrophobins. EMBO J 17:38383849 
Kertesz-Chaloupková K, Walser PJ, Granado JD, Aebi M, Kües U (1998) Blue light overrides repression of a-sexual sporulation by mating type genes in the basidiomycete Coprinus cinereus. Fungal Genet Biol 23:95-109

Kim H, Han K, Kim K, Han D, Jahng K, Chae K (2002) The veA gene activates sexual development in Aspergillus nidulans. Fungal Genet Biol 37:72-80

Klengel T, Liang WJ, Chaloupka J, Ruoff C, Schröppel K, Naglik JR, Eckert SE, Mogensen EG, Haynes K, Tuite MF, Levin LR, Buck J, Mühlschlegel FA (2005) Fungal adenylyl cyclase integrates CO2 sensing with cAMP signaling and virulence. Curr Biol 15:2021-2026

Knabe N, Jung E-M, Freihorst D, Hennicke F, Horton JS, Kothe E (2013) A central role for Ras1 in morphogenesis of the basidiomycete Schizophyllum commune. Eukaryot Cell 12(6):941-952

Koltin Y (1970) Development of the AmutBmut strain of Schizophyllum commune. Arch Microbiol 74:123-128

Kothe E (2001) Mating-type genes for basidiomycete strain improvement in mushroom farming. Appl Microbiol Biotechnol 56:602-612

Kües U (2000) Life history and developmental processes in the basidiomycete Coprinus cinereus. Microbiol Mol Biol Rev 64:316-353

Kües U, Liu Y (2000) Fruiting body production in basidiomycetes. Appl Microbiol Biotechnol 54:141-152

Kües U, Künzler M, Bottoli APF, Walser PJ, Granado JD, Yi L, Bertossa RC, Ciardo D, Clergeot P-H, Loos S, Ruprich-Robert G, Aebi M (2004) Mushroom development in higher basidiomycetes; implications for human and animal health. In: Kushwaha RKS (ed) Fungi in human and animal health. Scientific, Jodhpur, India, pp 431-469

Kües U, Badalyan SM, Gießler A, Dörnte B (2016) Asexual sporulation in agaricomycetes. In: Wendland J (ed) Growth, differentiation and sexuality. Springer, Cham, pp 269-328

Kuratani M, Tanaka K, Terashima K, Muraguchi H, Nakazawa T, Nakahori K, Kamada T (2010) The $d s t 2$ gene essential for photomorphogenesis of Coprinopsis cinerea encodes a protein with a putative FAD-binding-4 domain. Fungal Genet Biol 47:152-158

Lee BN, Adams TH (1994) Overexpression of $f l b A$, an early regulator of Aspergillus asexual sporulation, leads to activation of $b r l A$ and premature initiation of development. Mol Microbiol 14:323-334

Lengerer KB, Fox DS, Fraser JA, Allen A, Forrester K, Dietrich FS, Heitman J (2002) Mating-type locus of Cryptococcus neoformans: a step in the evolution of sex chromosomes. Eukaryot Cell 1(5):704-718

Lu BC (1974) Meiosis in Coprinus. Role of light on basidiocarp initiation, mitosis, and hymenium differentiation in Coprinus lagopus. Can J Bot 52:299-308
Lu BC (2000) The control of meiosis progression in the fungus Coprinus cinereus by light/dark cycles. Fungal Genet Biol 31:33-41

Luan R, Liang Y, Chen Y, Liu H, Jiang S, Che T, Wong B, Sun Hui H (2010) Opposing developmental functions of Agrocybe aegerita galectin (AAL) during mycelia differentiation. Fungal Biol 114(8):599-608

Lugones LG, Bosscher JS, Scholtmeijer K, de Vries OMH, Wessels JGH (1996) An abundant hydrophobin (ABH1) forms hydrophobic rodlet layers in Agaricus bisporus fruiting bodies. Microbiology 142:1321-1329

Lugones LG, Wösten HAB, Wessels JGH (1998) A hydrophobin $(\mathrm{ABH} 3)$ secreted by the substrate mycelium of Agaricus bisporus (common white button mushroom). Microbiology 144:2345-2353

Lugones LG, Wösten HAB, Birkenkamp KU, Sjollema KA, Zagers J, Wessels JGH (1999) Hydrophobins line air channels in fruiting bodies of Schizophyllum commune and Agaricus bisporus. Mycol Res 103:635-640

Lugones LG, de Jong JF, de Vries OMH, Jalving R, Dijksterhuis J, Wösten HAB (2004) The SC15 protein of Schizophyllum commune mediates formation of aerial hyphae and attachment in the absence of the SC3 hydrophobin. Mol Microbiol 53(2):707-716

Madelin MF (1956) The influence of light and temperature on fruiting of Coprinus lagopus Fr. in pure culture. Ann Bot 20:467-480

Manachère G (1980) Conditions essential for controlled fruiting of macromycetes-A review. Trans Brit Mycol Soc 75:255-270

Manachère G (1988) Regulation of sporophore differentiation in some macromycetes, particularly in Coprini: An overview of some experimental studies from fruiting initiation to sporogenesis. Cryptogamie Mycol 9:291-323

Matsumoto T, Kitamoto Y (1987) Induction of fruitbody formation by water-flooding treatment in sawdust cultures of Lentinus edodes. Trans Mycol Soc Jpn 28:437-443

McQueen-Mason SJ, Cosgrove DJ (1995) Expansin mode of action on cell walls. Analysis of wall hydrolysis, stress relaxation, and binding. Plant Physiol 107(1):87-100

McQueen-Mason S, Durachko DM, Cosgrove DJ (1992) Two endogenous proteins that induce cell wall extension in plants. Plant Cell 4(11):1425-1433

Meskauskas A, McNulty LJ, Moore D (2004) Concerted regulation of all hyphal tips generates fungal fruit body structures: experiments with computer visualizations produced by a new mathematical model of hyphal growth. Mycol Res 108:341-353

Mogensen EG, Janbon G, Chaloupka J, Steegborn C, Fu MS, Moyrand F, Klengel T, Pearson DS, Geeves MA, Buck J, Levin LR, Mühlschlegel FA (2006) Cryptococcus neoformans senses $\mathrm{CO}_{2}$ through the 
carbonic anhydrase Can2 and the adenylyl cyclase Cac1. Eukaryot Cell 5:103-111

Moore D (1998) Fungal morphogenesis. Cambridge University Press, Cambridge

Moore D, Casselton LA, Wood DA, Frankland JC (eds) (1985) Developmental biology of higher fungi. Cambridge University Press, Cambridge

Morin E, Kohler A, Baker AR, Foulongne-Oriol M, Lombard V, Nagy LG, Ohm RA, Patyshakuliyeva A, Brun A, Aerts AL et al (2012) Genome sequence of the button mushroom Agaricus bisporus reveals mechanisms governing adaptation to a humic-rich ecological niche. Proc Natl Acad Sci USA 109 (43):17501-17506

Moukha SM, Wösten HAB, Asther M, Wessels JGH (1993) In situ localization of lignin peroxidase excretion in colonies of Phanerochaete chrysosporium using sandwiched mode of culture. J Gen Microbiol 139:969-978

Mulder GH, Wessels JGH (1986) Molecular cloning of RNAs differentially expressed in monokaryons and dikaryons of Schizophyllum commune. Exp Mycol 10:214-227

Muraguchi H, Kamada T (1998) The ich1 gene of the mushroom Coprinus cinereus is essential for pileus formation in fruiting. Development 125:3133-3141

Muraguchi H, Kamada T (2000) A mutation in the eln2 gene encoding a cytochrome P450 of Coprinus cinereus affects mushroom morphogenesis. Fungal Genet Biol 29:49-59

Muraguchi H, Takemaru T, Kamada K (1999) Isolation and characterization of developmental variants in fruiting using a homokaryotic fruiting strain of Coprinus cinereus. Mycoscience 40:227-235

Murata Y, Fujii M, Zolan ME, Kamada T (1998) Molecular analysis of $p c c 1$, a gene that leads to $A$-regulated sexual morphogenesis in Coprinus cinereus. Genetics 149:1753-1761

Nakazawa T, Miyazaki Y, Kaneko S, Shishido K (2008) Stimulative effects of light and a temperature downshift on transcriptional expressions of developmentally regulated genes in the initial stages of fruiting-body formation of the basidiomycetous mushroom Lentinula edodes. FEMS Microbiol Lett 289:67-71

Nakazawa T, Ando Y, Kitaaki K, Nakahori K, Kamada T (2011) Efficient gene targeting in $\Delta C c . k u 70$ or $\Delta C c$. lig4 mutants of the agaricomycete Coprinopsis cinerea. Fungal Genet Biol 48:939-946

Nayak AP, Green BJ, Beezhold DH (2013) Fungal hemolysins. Med Mycol 51:1-16

Ni M, Feretzaki M, Li W, Floyd-Averette A, Mieczkowski P, Dietrich FS, Heitman J (2013) Unisexual and heterosexual meiotic reproduction generate aneuploidy and phenotypic diversity de novo in the yeast Cryptococcus neoformans. PLoS Biol 11, e1001653

Niederpruem DJ (1963) Role of carbon dioxide in the control of fruiting of Schizophyllum commune. J Bacteriol 85:1300-1308
Ohm RA, de Jong JF, Lugones LG, Aerts A, Kothe E, Stajich JE, de Vries RP, Record E, Levasseur A, Baker SE, Bartholomew KA, Coutinho PM, Erdmann S, Fowler TJ, Gathman AC, Lombard V, Henrissat B, Knabe N, Kües U, Lilly WW, Lindquist E, Lucas S, Magnuson JK, Piumi F, Raudaskoski M, Salamov A, Schmutz J, Schwarze FW, vanKuyk PA, Horton JS, Grigoriev IV, Wösten HAB (2010) Genome sequence of the model mushroom Schizophyllum commune. Nat Biotechnol 28:957-963

Ohm RA, de Jong JF, de Bekker C, Wösten HAB, Lugones LG (2011) Transcription factor genes of Schizophyllum commune involved in regulation of mushroom formation. Mol Microbiol 81:14331445

Ohm RA, Aerts D, Wösten HAB, Lugones LG (2013) The blue light receptor complex WC-1/2 of Schizophyllum commune is involved in mushroom formation and protection against phototoxicity. Environ Microbiol 15:943-955

Perkins JH (1969) Morphogenesis in Schizophyllum commune. I. Effects of white light. Plant Physiol 44:1706-1711

Plaza DF, Lin CW, van der Velden NSJ, Aebi M, Künzler M (2014) Comparative transcriptomics of the model mushroom Coprinopsis cinerea reveals tissue-specific armories and a conserved circuitry for sexual development. BMC Genomics 15:492

Purschwitz J, Müller S, Kastner C, Fischer R (2006) Seeing the rainbow: light sensing in fungi. Curr Opin Microbiol 9:566-571

Purschwitz J, Müller S, Kastner C, Schöser M, Haas H, Espeso EA, Atoui A, Calvo AM, Fischer R (2008) Functional and physical interaction of blue- and red-light sensors in Aspergillus nidulans. Curr Biol 18:255-259

Quiroz-Castañeda RE, Martínez-Anaya C, Cuervo-Soto LI, Segovia L, Folch-Mallol JL (2011) Loosenin, a novel protein with cellulose-disrupting activity from Bjerkandera adusta. Microb Cell Factories 10:8

Raper CA (1976) Sexuality and life cycle of the edible, wild Agaricus bitorquis. J Gen Microbiol 95:54-66

Raper JR, Miles PG (1958) The genetics of Schizophyllum commune. Genetics 43:530-546

Raper JR, Boyd DH, Raper CA (1965) Primary and secondary mutations at the incompatibility loci in Schizophyllum. Proc Natl Acad Sci USA 53:1324-1332

Raper CA, Raper JR, Miller RE (1972) Genetic analysis of the life cycle of Agaricus bisporus. Mycologia 64:1088-1117

Raudaskoski M, Vauras R (1982) Scanning electron microscope study of fruit body differentiation in Schizophyllum commune. Trans $\mathrm{Br}$ Mycol Soc 78:89-96

Raudaskoski M, Viitanen H (1982) Effects of aeration and light on fruit-body induction in Schizophyllum commune. Trans Br Mycol Soc 78:89-96 
Raudaskoski M, Yli-Mattila T (1985) Capacity for photoinduced fruiting in the dikaryon of Schizophyllum commune. Trans Br Mycol Soc 85:145-151

Reijnders AFM, Stafleu JA (1992) The development of the hymenophoral trama in the Aphylophorales and Agaricales. Stud Mycol 34:1-109

Ruiters MHJ, Sietsma JH, Wessels JGH (1988) Expression of dikaryon-specific mRNAs of Schizophyllum commune in relation to incompatibility genes, light, and fruiting. Exp Mycol 12:60-69

Sánchez C (2010) Cultivation of Pleurotus ostreatus and other edible mushrooms. Appl Microbiol Biotechnol 85(5):1321-1337

Sánchez C, Moore D (1999) Conventional histological stains selectively stain fruit body initials of basidiomycetes. Mycol Res 103:315-318

Sánchez C, Tellez-Tellez M, Diaz-Godinez G, Moore D (2004) Simple staining detects ultrastructural and biochemical differentiation of vegetative hyphae and fruit body initials in colonies of Pleurotus pulmonarius. Lett Appl Microbiol 38:483-487

Sarikaya Bayram O, Bayram O, Valerius O, Park HS, Irniger S, Gerke J, Ni M, Han KH, Yu JH, Braus GH (2010) LaeA control of velvet family regulatory proteins for light-dependent development and fungal cell-type specificity. PLoS Genet 6, e1001226

Scholtmeijer K, de Vocht ML, Rink R, Robillard GT, Wösten HAB (2009) Assembly of the fungal SC3 hydrophobin into functional amyloid fibrils depends on its concentration and is promoted by cell wall polysaccharides. J Biol Chem 284:2630926314

Schubert D, Raudaskoski M, Knabe N, Kothe E (2006) Ras GTPase-activating protein Gap1 of the homobasidiomycete Schizophyllum commune regulates hyphal growth orientation and sexual development. Eukaryot Cell 5(4):683-695

Schuren FHJ (1999) Atypical interactions between the thn and wild-type mycelia of Schizophyllum commune. Mycol Res 103:1540-1544

Schuren FHJ, Wessels JGH (1990) Two genes specifically expressed in fruiting dikaryons of Schizophyllum commune: homologies with a gene not regulated by mating-type genes. Gene 90:199-205

Schuurs TA, Dalstra HJP, Scheer JMJ, Wessels JGH (1998) Positioning of nuclei in secondary mycelium of Schizophyllum commune in relation to differential gene expression. Fungal Genet Biol 23:150-161

Schwalb MN, Miles PG (1967) Morphogenesis of Schizophyllum commune. I. Morphological variation and mating behaviour of the thin mutation. Am J Bot 54:440-446

Singh RS, Bhari R, Kaur HP (2010) Mushroom lectins: current status and future perspectives. Crit Rev Biotechnol 30:99-126

Springer J, Wessels JGH (1989) A frequently occurring mutation that blocks the expression of fruiting genes in Schizophyllum commune. Mol Gen Genet 219:486-488
Sun H, Zhao CG, Tong X, Qi YP (2003) A lectin with mycelia differentiation and antiphytovirus activities from the edible mushroom Agrocybe aegerita. J Biochem Mol Biol 36:214-222

Suzuki H, Vuong TV, Gong Y, Chan K, Ho C-Y, Master ER, Kondo A (2014) Sequence diversity and gene expression analyses of expansin-related proteins in the white-rot basidiomycete, Phanerochaete carnosa. Fungal Genet Biol. doi:10.1016/j. fgb.2014.05.008

Swamy S, Uno I, Ishikawa T (1984) Morphogenetic effects of mutations at the $A$ and $B$ incompatibility factors in Coprinus cinereus. J Gen Microbiol 130:3219-3224

Terashima K, Yuki K, Muraguchi H, Akiyama M, Kamada T (2005) The dst1 gene involved in mushroom photomorphogenesis of Coprinus cinereus encodes a putative photoreceptor for blue light. Genetics 171:101-108

Todd RB, Zhou M, Ohm RA, Leeggangers HACF, Visser L, de Vries RP (2014) Prevalence of transcription factors in ascomycete and basidiomycete fungi. BMC Genomics 15:240

Tsusué YM (1969) Experimental control of fruit-body formation in Coprinus macrorhizus. Dev Growth Diff 11:164-178

Ullrich RC, Anderson JB (1978) Sex and diploidy in Armillaria mellea. Exp Mycol 2:119-129

Umar MH, van Griensven LJLD (1997) Morphogenetic cell death in developing primordia of Agaricus bisporus. Mycologia 89:274-277

Uno I, Ishikawa T (1971) Chemical and genetical control of induction of monokaryotic fruiting bodies in Coprinus macrorhizus. Mol Gen Genet 113:228-239

van der Valk P, Marchant R (1978) Hyphal ultrastructure in fruit body primordial of the basidiomycetes Schizophyllum commune and Coprinus cinereus. Protoplasma 95:57-72

van Driel KGA, Van Peer AF, Grijpstra J, Wösten HAB, Verkleij AJ, Müller WH, Boekhout T (2008) Septal pore cap protein SPC18, isolated from the basidiomycetous fungus Rhizoctonia solani, also resides in pore plugs. Eukaryot Cell 7(10):1865-1873

van Griensven LJLD (ed) (1988) The cultivation of mushrooms. Darlington Mushroom Laboratories, Rustington, Sussex

van Peer AF, Müller WH, Boekhout T, Lugones LG, Wösten HAB (2009) Cytoplasmic continuity revisited: closure of septa of the filamentous fungus Schizophyllum commune in response to environmental conditions. PLoS ONE 4(6)

van Peer AF, Wang F, van Driel KGA, de Jong JF, van Donselaar EG, Müller WH, Boekhout T, Lugones LG, Wösten HAB (2010) The septal pore cap is an organelle that functions in vegetative growth and mushroom formation of the wood-rot fungus Schizophyllum commune. Environ Microbiol 12 (4):833-844 
van Wetter MA, Wösten HAB, Wessels JGH (2000a) SC3 and SC4 hydrophobins have distinct functions in formation of aerial structures in dikaryons of Schizophyllum commune. Mol Microbiol 36:201-210

van Wetter MA, Wösten HAB, Sietsma JH, Wessels JGH (2000b) Hydrophobin gene expression affects hyphal wall composition in Schizophyllum commune. Fungal Genet Biol 31:99-104

Vidic I, Berne S, Drobne D, Maček P, Frangež R, Turk T, Štrus J, Sepčić K (2005) Temporal and spatial expression of ostreolysin during development of the oyster mushroom (Pleurotus ostreatus). Mycol Res 109(3):377-382

Watling R (1996) Patterns in fungal development fruiting patterns in nature. In: Chiu S-W, Moore $\mathrm{D}$ (eds) Patterns in fungal development. Cambridge University Press, Cambridge

Weber M, Salo V, Uuskallio M, Raudaskoski M (2005) Ectopic expression of a constitutively active Cdc42 small GTPase alters the morphology of haploid and dikaryotic hyphae in the filamentous homobasidiomycete Schizophyllum commune. Fungal Genet Biol 42(7):624-637

Wells K, Wells EK (eds) (1982) Basidium and basidiocarp. Springer, New York

Wessels JGH (1965) Morphological and biochemical processes in Schizophyllum commune. Wentia 13:1-113

Wessels JGH (1986) Cell wall synthesis in apical hyphal growth. Int Rev Cytol 104:37-79

Wessels JGH (1990) Role of cell wall architecture in fungal tip growth generation. In: Heath IB (ed) Tip growth of plant and fungal cells. Academic, San Diego, pp 1-29

Wessels JGH (1993) Fruiting in the higher fungi. Adv Microb Physiol 34:147-202

Wessels JGH (1994) Developmental regulation of fungal cell wall formation. Annu Rev Phytopathol 32:413-437

Wessels JGH (1997) Hydrophobins: proteins that change the nature of the fungal surface. Adv Microb Physiol 38:1-45

Wessels JGH, Marchant JR (1974) Enzymatic degradation in hyphal wall preparations from a monokaryon and a dikaryon of Schizophyllum commune. J Gen Microbiol 83:359-368

Wessels JGH, Mulder GH, Springer J (1987) Expression of dikaryon-specific and non-specific mRNAs of Schizophyllum commune in relation to environmental conditions and fruiting. J Gen Microbiol 133:2557-2561

Wessels JGH, de Vries OMH, Ásgeirsdóttir SA, Schuren FHJ (1991a) Hydrophobin genes involved in formation of aerial hyphae and fruit bodies in Schizophyllum. Plant Cell 3:793-799

Wessels JGH, de Vries OMH, Ásgeirsdóttir SA, Springer J (1991b) The thn mutation of Schizophyllum commune, which suppresses formation of aerial hyphae, affects expression of the $S c 3$ hydrophobin gene. J Gen Microbiol 137:2439-2445
Wessels JGH, Ásgeirsdóttir SA, Birkenkamp KU, de Vries OMH, Lugones LG, Scheer JMJ, Schuren FHJ, Schuurs TA, van Wetter M-A, Wösten $\mathrm{HAB}$ (1995) Genetic regulation of emergent growth in Schizophyllum commune. Can J Bot 73: S273-S281

Wessels JGH, Schuurs TA, Dalstra HJP, Scheer JMJ (1998) Nuclear distribution and gene expression in the secondary mycelium of Schizophyllum commune. In: Gow N, Robson G, Gadd G (eds) The fungal colony. Cambridge University Press, Cambridge, pp 302-325

Whitehouse HLK (1949) Multiple allelomorph heterothallism in the fungi. New Phytol 48:212-244

Wiemer M, Grimm C, Osiewacz HD (2016) Molecular control of fungal senescence and longevity. In: Wendland J (ed) Growth, differentiation and sexuality. Springer, Cham, pp 155-181

Woolston BM, Schlagnhaufer C, Wilkinson J, Larsen J, Shi Z, Mayer KM, Walters DS, Curtis WR, Romaine CP (2011) Long-distance translocation of protein during morphogenesis of the fruiting body in the filamentous fungus, Agaricus bisporus. PLoS ONE 6, e28412

Wösten HAB (2001) Hydrophobins: multipurpose proteins. Annu Rev Microbiol 55:625-646

Wösten HAB, de Vocht ML (2000) Hydrophobins, the fungal coating unravelled. Biochim Biophys Acta Rev Biomembranes 1469:79-86

Wösten HAB, Wessels JGH (1997) Hydrophobins, from molecular structure to multiple functions in fungal development. Mycoscience 38:363-374

Wösten HAB, Willey JM (2000) Surface active proteins enable microbial aerial hyphae to grow into the air. Microbiology 146:767-773

Wösten HAB, Moukha SM, Sietsma JH, Wessels JGH (1991) Localization of growth and secretion of proteins in Aspergillus niger. J Gen Microbiol 137:2017-2024

Wösten HAB, de Vries OMH, Wessels JGH (1993) Interfacial self-assembly of a fungal hydrophobin into a hydrophobic rodlet layer. Plant Cell 5:1567-1574

Wösten HAB, Ásgeirsdóttir SA, Krook JH, Drenth JHH, Wessels JGH (1994a) The Sc3p hydrophobin selfassembles at the surface of aerial hyphae as a protein membrane constituting the hydrophobic rodlet layer. Eur J Cell Biol 63:122-129

Wösten HAB, Schuren FHJ, Wessels JGH (1994b) Interfacial self-assembly of a hydrophobin into an amphipathic membrane mediates fungal attachment to hydrophobic surfaces. EMBO J 13:58485854

Wösten HAB, Ruardy TG, van der Mei HC, Busscher HJ, Wessels JGH (1995) Interfacial self-assembly of a Schizophyllum commune hydrophobin into an insoluble amphipathic membrane depends on surface hydrophobicity. Coll Surf B Biointerface 5:189-195

Wösten $\mathrm{HAB}$, van Wetter MA, Lugones LG, van der Mei HC, Busscher HJ, Wessels JGH (1999) How a fun- 
gus escapes the water to grow into the air. Curr Biol 9:85-88

Wösten HAB, van Veluw GJ, de Bekker C, Krijgsheld P (2013) Heterogeneity in the mycelium: implications for the use of fungi as cell factories. Biotechnol Lett 35:1155-1164

Yamagishi K, Kimura T, Suzuki M, Shinmoto H (2002) Suppression of fruit-body formation by constitutively active G-protein alpha-subunits ScGP-A and ScGP-C in the homobasidiomycete Schizophyllum commune. Microbiology 148:2797-2809
Yamagishi K, Kimura T, Suzuki M, Shinmoto H, Yamaki KJ (2004) Elevation of intracellular cAMP levels by dominant active heterotrimeric $\mathrm{G}$ protein alpha Subunits ScGP-A and ScGP-C in homobasidiomycete, Schizophyllum commune. Biosci Biotechnol Biochem 68:1017-1026

Zhang W, Wu X, Zhou Y, Liu Z, Zhang W, Niu X, Zhao Y, Pei S, Zhao Y, Yuan S (2014) Characterization of stipe elongation of the mushroom Coprinus cinereus. Microbiology. doi:10.1099/ mic.0.079418-0 